\title{
AC 2008-1867: USE OF SPREADSHEETS IN SOLVING HEAT CONDUCTION PROBLEMS IN FINS
}

\section{Amir Karimi, University of Texas-San Antonio}

AMIR KARIMI Amir Karimi is a Professor of Mechanical Engineering and an Associate Dean of Undergraduate Studies at The University of Texas at San Antonio (UTSA). He received his Ph.D. degree in Mechanical Engineering from the University of Kentucky in 1982. His teaching and research interests are in thermal sciences. He has served as the Chair of Mechanical Engineering (1987 to 1992 and September 1998 to January of 2003), College of Engineering Associate Dean of Academic Affairs (Jan. 2003-April 2006), and the Associate Dean of Undergraduate Studies (April 2006-present). Dr. Karimi is a Fellow of ASME, senior member of AIAA, and holds membership in ASEE, ASHRAE, and Sigma Xi. He is the ASEE Campus Representative at UTSA, ASEE-GSW Section Campus Representative, and served as the Chair of ASEE Zone III (2005-07). He chaired the ASEE-GSW section during the 1996-97 academic year. 


\title{
Use of Spreadsheets in Solving Heat Conduction Problems in Fins
}

\begin{abstract}
Excel is an effective and inexpensive tool available on all computers equipped with Microsoft Office. This software has the necessary functions for solving a large class of engineering problems, including those related to heat transfer. This paper provides several examples to demonstrate the application of Excel in solving problems involving one-dimensional heat conduction in various fin configurations. It provides formulas for the temperature distribution and heat transfer for several different fin profiles.
\end{abstract}

\section{Introduction}

An introductory course in heat transfer typically covers the basic analysis of one-dimensional heat conduction problems involving fins with simple geometrical configurations. The analytical coverage is usually limited to fins of uniform cross-sectional area. For more complex fin configurations, only fin efficiency charts are provided in most heat transfer textbooks. ${ }^{1-15}$ These charts approximate the rate of heat transfer, but do not provide any information on the temperature distribution in fins. Microsoft Excel, can be a useful tools in solving heat conduction problems for a variety of fin configurations.

Numerical solution of heat transfer problems has been an evolving phenomenon. In the early stages, the application tools have undergone a gradual progression through slide rules, simple calculators, mainframe computers, desktop and laptop computers. Prior to 1972, slide rules were the essential computational tools for solving engineering problems and computers were seldom used for analysis of heat transfer problems at the undergraduate level. Many of the more complex analytic solutions to heat transfer problems were given in graphs or charts. A few examples include graphs for fin efficiencies, transient temperature distribution charts for heat transfer in slabs, cylinders, or spheres (Heisler Charts), and radiation shape (view) factor charts.

In the early 1970's calculators replaced slide rules as the basic computational tool for solving engineering problems. A few years later programmable calculators were available. Modules containing basic solutions to heat transfer problems were developed for these calculators. Authors included sections in their textbooks to introduce students to numerical techniques for solving heat transfer problems.

The computer application software for solving engineering problems has also changed. Prior to the introduction of personal computers (PCs) in the early 1980's, complex computer codes were needed for numerical solution of heat transfer problems and the knowledge of a computer programming language was essential for integrating numerical solutions into heat transfer courses. Access to mainframe computers and proficiency in such programming languages as FORTRAN and PASCAL were necessary for solving complex heat transfer problems. Therefore, mechanical engineering programs required a course in one of the structured computer programming languages. 
As personal computers became more available and affordable, and as the operating systems became more user friendly, their applications were gradually integrated into introductory heat transfer courses. BASIC programming language was used for solving simple heat transfer problems. In more recent years, the trend has shifted toward using software packages for solving numerical problems and many mechanical engineering degree programs no longer require a course in computer programming.

Integration of computer software in heat transfer courses enhances the student learning experience and aids the understanding of basic concepts and fundamental physical laws. Many publishing companies provide computer software with heat transfer textbooks. ${ }^{8-15}$ Most commonly used software tools in heat transfer courses are Interactive Heat Transfer (IHT) ${ }^{16}$ and Engineering Equation Solver (EES). ${ }^{17}$ These programs are general purpose, non-linear equation solvers with built-in property functions. They are capable of exploring and graphing the effects of change in variables on the solution to a given problem. There are other software packages available in the market that can be integrated into a heat transfer course. These include Microsoft Excel spreadsheet, Mathcad, MATLAB, and Maple.

All available software packages are extremely useful tools for analysis and design in undergraduate or graduate introductory heat transfer courses. The most significant advantage of these software programs is that no prior knowledge of programming language is necessary in their applications. Excel is an example of these application software programs. The focus of this paper is to describe how Excel could be used in the heat transfer analysis of extended surfaces.

\section{Excel Spreadsheet}

It has been shown ${ }^{18,19}$ that Excel is an effective computational tool in solving boundary layer problems. Excel operates with data entered by the user into a spreadsheet. This software recognizes 39 engineering functions, as well as various math and trigonometry functions. The engineering functions include Bessel functions, error functions, and other functions used in heat transfer.

To insert engineering functions in the formulas, the insert button on the Excel spreadsheet could be used. Then clicking on function, a window appears on the screen, as shown on Fig. 1. One can search for the desired function by typing a description of the function (financial, engineering, etc.) in the search box or using the "select category" box by scrolling through options for the desired function.

For problems requiring iterative calculations, the "Goal Seek" or "Solver" tools can be employed. By using the tool menu, and selecting the solver option a dialog box appears, as shown in Fig 1. By selecting the target cell and fixing the desired value for that cell, values in the selected cells automatically change to correspond to the solution given for the target cell. This will be demonstrated later in an example. 

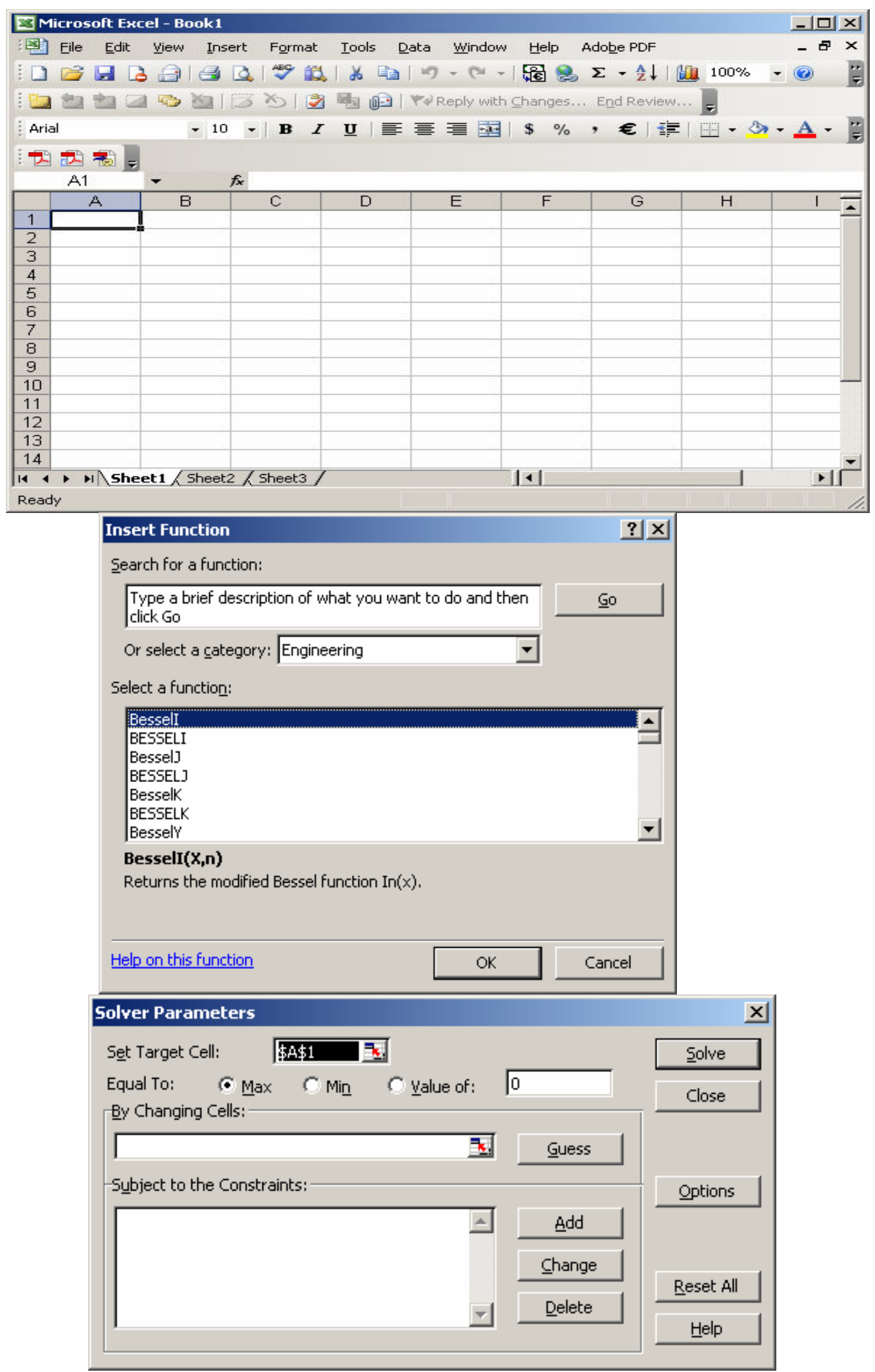

Fig. 1. Excel worksheet, function selection menu, and solver window 


\section{One Dimensional Heat Conduction in Fins}

Heat transfer analysis of heat conduction in straight fins of uniform cross-sectional area is included in heat transfer text books. The analysis results in formulas for temperature distribution, the rate of heat exchange with the surrounding environment, and the fin efficiency. Boundary conditions used in the analysis will influence the resulting equations. For example, for an infinitely long fin of a uniform cross-sectional area the temperature distribution and heat transfer are given by the following equations.

$$
\begin{aligned}
& \theta=\frac{T-T_{\infty}}{T_{o}-T_{\infty}}=e^{-m x} \\
& q=\sqrt{h P k A}\left(T-T_{o}\right)
\end{aligned}
$$

where, $m=\sqrt{h P / k A}, \mathrm{P}$ denotes the perimeter, $\mathrm{h}$ is the heat transfer coefficient, $\mathrm{k}$ is the thermal conductivity, $\mathrm{A}$ is the cross-sectional area, $\mathrm{T}_{\mathrm{o}}$ is the temperature at the base of fin, and $\mathrm{T}_{\infty}$ is the ambient temperature.

For a fin of uniform cross-sectional area with insulated tip, the temperature distribution and heat transfer can be expressed, respectively, as

$$
\begin{aligned}
& \theta=\frac{T-T_{\infty}}{T_{o}-T_{\infty}}=\frac{\cosh [m(L-x)]}{\cosh (m L)} \\
& q=\sqrt{h P k A}\left(T-T_{o}\right) \tanh (m L)
\end{aligned}
$$

where, $\mathrm{L}$ is the length of the fin.

If the tip of the fin is exposed to a convective environment, equations for the temperature distribution and heat transfer are given by

$$
\begin{aligned}
& \theta=\frac{T-T_{\infty}}{T_{o}-T_{\infty}}=\frac{\cosh [m(L-x)]+\left(h_{t i p} / m k\right) \sinh [m(L-x)]}{\cosh (m L)+\left(h_{t i p} / m k\right) \sinh (m L)} \\
& q=\sqrt{h P / k A}\left(T-T_{o}\right)\left[\frac{\cosh m L+\left(h_{t i p} / m k\right) \sinh (m L)}{\cosh (m L)+\left(h_{t i p} / m k\right) \sinh (m L)}\right]
\end{aligned}
$$

Where, $\mathrm{h}_{\text {tip }}$ represents the heat transfer coefficient at the tip of fin.

If the temperature at the tip of the fin is given, the temperature distribution and heat transfer equations are given by 


$$
\begin{gathered}
\theta=\frac{T-T_{\infty}}{T_{o}-T_{\infty}}=\frac{\left[\left(T_{L}-T_{\infty}\right) /\left(T_{o}-T_{\infty}\right)\right] \sinh (m x)+\sinh [m(L-x)]}{\sinh (m L)} \\
q=\sqrt{h P / k A}\left(T-T_{o}\right)\left[\frac{\cosh m L+\left[\left(T_{L}-T_{\infty}\right) /\left(T_{o}-T_{\infty}\right)\right]}{\sinh (m L)}\right]
\end{gathered}
$$

where, $T_{L}$ represents the temperature at the tip of the fin.

It should be noted that the equations presented in this section for the temperature profile and heat transfer are based on the assumption of one-dimensional heat conduction in the axial direction of the fin. For this assumption to be valid, the Biot number, Bi, must satisfy the following condition

$$
B i=\frac{h L_{c h}}{k}=\frac{h(A / P)}{k} \pi 0.1
$$

where, $\mathrm{L}_{\mathrm{ch}}$ is a characteristic length, $\mathrm{A}$ is the cross sectional area, and $\mathrm{P}$ is the perimeter of the fin. For fins of circular cross sectional area, $\mathrm{L}_{\mathrm{ch}}$ can be represented by the radius, $\mathrm{R}$.

Analysis for fins of variable cross-sectional areas or annular fins results in more complex differential equations. The solutions include more complex functions, including Bessel functions. The analyses for these types of fins are not typically fully covered in an introductory heat transfer course. Instead the results are shown in the form of fin efficiency charts. In very few cases, equations or graphs for temperature distributions are provided. For several common fins, the equations for temperature profile are included in the appendix.

Several modern textbooks ${ }^{9-12}$ provide expressions for the efficiency of most common fin shapes. A list of equations for fin efficiencies is included in the appendix. The fin efficiency is defined as

$$
\eta_{f}=\frac{q_{a c t}}{q_{\max }}=\frac{q_{a c t}}{h A\left(T_{o}-T_{\infty}\right)}
$$

where, $\mathrm{q}_{\text {act }}$ denotes the actual heat transfer, $\mathrm{q}_{\max }$ represents the maximum theoretical heat transfer by assuming that the entire fine is at the base temperature. For types of fins not included in the appendix, additional expressions for temperature distribution and efficiency are included in the book on Extended Surface Heat Transfer. ${ }^{20}$

A few examples are provided in the following section to demonstrate the use of Excel spreadsheets in solving heat transfer problems involving fins.

\section{Example 1:}

A straight fin of triangular profile (axial section) $0.1 \mathrm{~m}$ in length, $0.02 \mathrm{~m}$ thick at the base, and $0.2 \mathrm{~m}$ in depth is used to extend the surface of a wall at $200^{\circ} \mathrm{C}$. The wall and the fin are made of mild steel $\left(\mathrm{k}=54 \mathrm{~W} / \mathrm{m} .{ }^{\circ} \mathrm{C}\right)$. Air at $10{ }^{\circ} \mathrm{C}\left(\mathrm{h}=200 \mathrm{~W} / \mathrm{m}^{2} \cdot{ }^{\circ} \mathrm{C}\right)$ flows over the surface of the fin. Evaluate the temperature at $0.05 \mathrm{~m}$ from the base and at the tip of the fin. Determine the rate of 
heat removal from the fin and the fin efficiency ${ }^{21}$.

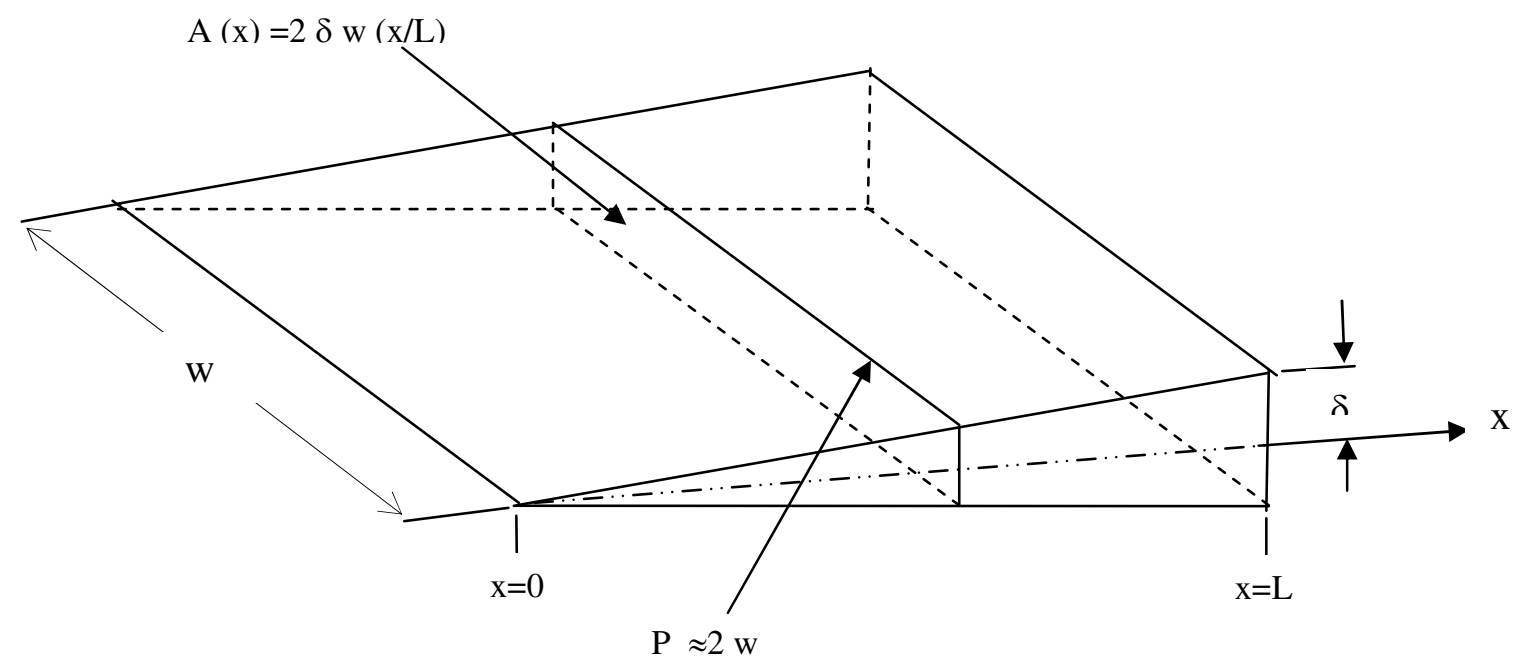

Fig. 2. Sketch of triangular fin in Example 1

\section{Solution}

An analytical solution to this problem ${ }^{7}$ gives the following expression for the dimensionless temperature distribution

$$
\theta=\frac{I_{o}(2 \sqrt{h L x / k \delta})}{I_{o}\left(2 \sqrt{h L^{2} / k \delta}\right)}=\frac{I_{o}(m \sqrt{L x})}{I_{o}(m \sqrt{L})}
$$

where, $\mathrm{L}$ is the length of the fin, $\mathrm{x}$ is the distance from the tip of the fin, $\delta$ is one half of the thickness at the base, $m=2 \sqrt{h / k \delta}$, and $\mathrm{I}_{0}$ is the modified Bessel function of the first kind of order zero.

The rate of heat removal can be calculated by evaluating heat transfer at the base of the fin, where $\mathrm{x}=\mathrm{L}$.

$$
q=-\left.k A \frac{d T}{d x}\right|_{x=L}
$$

Thus the rate of heat transfer at the base can be expressed by

$$
q=-2 w \sqrt{h k \delta}\left(T_{o}-T_{\infty}\right) \frac{I_{1}\left(2 \sqrt{h L^{2} / k \delta}\right)}{I_{o}\left(2 \sqrt{h L^{2} / k \delta}\right)}
$$

Where, w represents the width of the Then the rate of heat removal from the base is equal to $-\mathrm{q}$. Therefore, the fin efficiency can be determined by the following relation 


$$
\eta_{f}=\frac{-q}{2 h \sqrt{L^{2}+\delta^{2}}\left[w\left(T_{o}-T_{\infty}\right)\right]}
$$

The formulation of solution in Excel for this problem is shown in Fig. 3. The data given in the problem statement are first entered into the cells of the worksheet. Using these data, the formulas for evaluating $\mathrm{m}, \mathrm{mL}, m \sqrt{x L}, \mathrm{I}_{0}(\mathrm{~mL}), \mathrm{I}_{1}(\mathrm{~mL}), \mathrm{I}_{0}(\mathrm{~mL}), \mathrm{I}_{0}(m \sqrt{x L}), \theta, \mathrm{T}, \mathrm{q}$, and $\eta$ are entered into appropriate cells of the worksheet. To enter formulas an " $=$ " sign is first entered into the cell followed with the terms needed for the evaluation of the formula. The basic mathematic operators used are,,$+-{ }^{*}$ (multiplication), /, and ${ }^{\wedge}$ (power). The calculated results are presented in Fig. 4. By pressing CTRL +` (grave accent) one can switch between the worksheet displaying formulas and their resulting values.

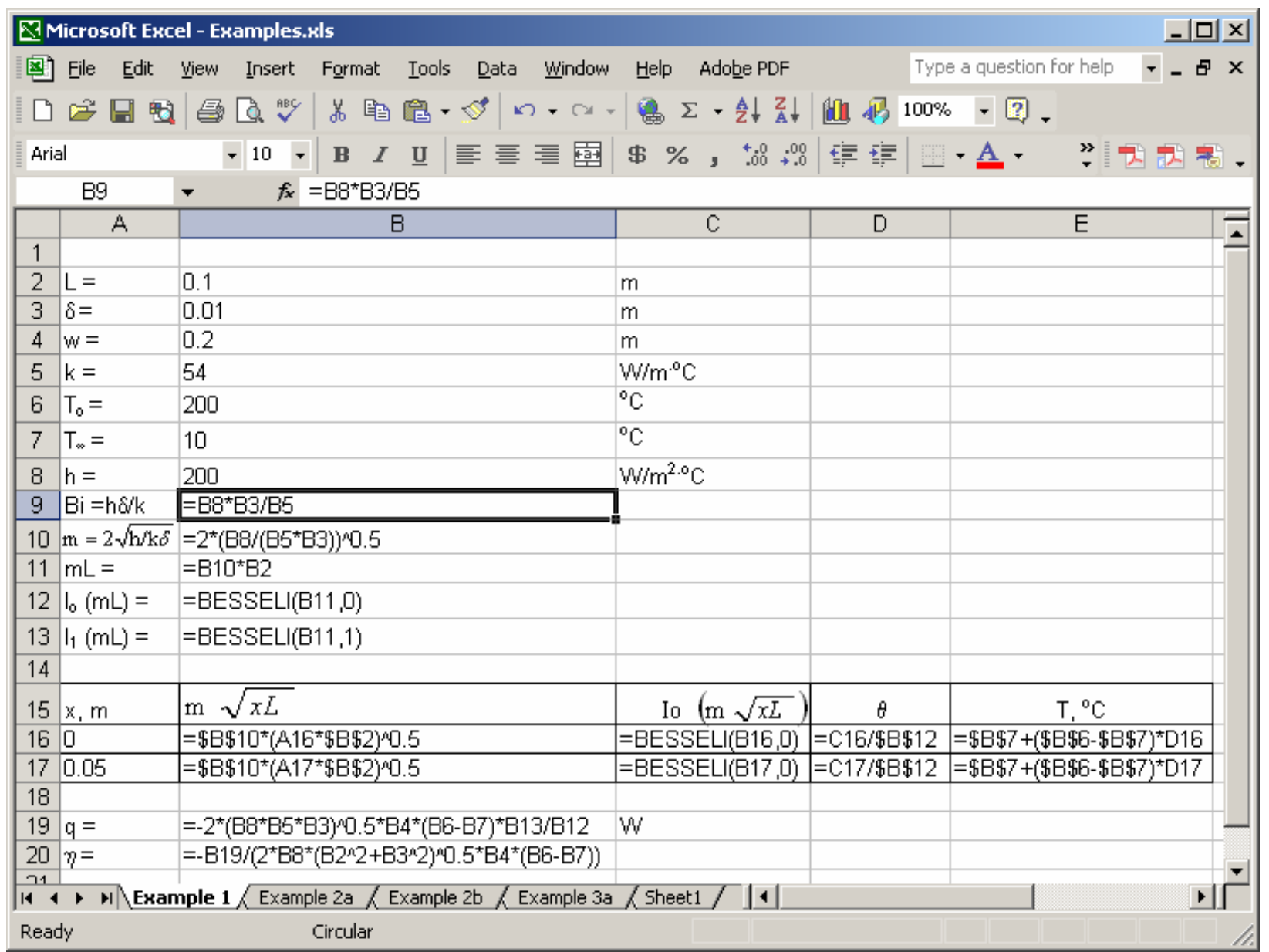

Fig. 3. Excel formulation of the solution for problem in Example 1.

The worksheet shown in Fig. 4 can be expanded to evaluate the temperature profile in the fin a, and plot the results. To achieve this, the values for $\mathrm{x}$ ranging between 0 and 0.1 are entered in column A (cells A16 through A-26), as shown in Fig. 5. Then the content of cells B16 through E16 is highlighted and copied into lower rows, by clicking on the bottom boundary corner of cell 
E16 and dragging it all the way to cell E26. By this copying actions the values of $m \sqrt{x L}$, $\mathrm{I}_{\mathrm{o}}(m \sqrt{x L}), \theta$, and $\mathrm{T}$ are automatically calculated for each value of $\mathrm{x}$ listed in column $\mathrm{A}$. To plot $\mathrm{T}$ as a function of $\mathrm{x}$, the cells A15 through A26 and E15 through E26 were first highlighted by pressing the Ctrl key. Then by clicking the chart wizard icon on the menu bar of the worksheet, a menu appears offering several standard options for plotting data. The $\mathrm{x}-\mathrm{y}$ (scatter) option was selected and the four steps of chart wizard were preformed by providing the necessary information in each step and pressing the next button. Finally the Finish button was pressed to show the results in the worksheet.

\begin{tabular}{|c|c|c|c|c|c|c|c|}
\hline \multicolumn{8}{|c|}{ هicrosoft Excel - Examples.rls } \\
\hline \multicolumn{2}{|c|}{$\begin{array}{l}\text { File Edit } \\
\text { Adobe PDF }\end{array}$} & View Ins & ert Format & Ioo & Is Data $\underline{\underline{w}}$ & $\begin{aligned} & \text { Window } \text { Help } \\
& \text { - }\end{aligned}$ & \\
\hline \multicolumn{2}{|c|}{ 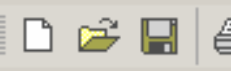 } & 寻 $\sqrt{\mathrm{ABC}}$ & $m \cdot \infty$ & $-\Sigma$ & - $100 \%$ & $\%=?$ & $\geqslant$ \\
\hline \multicolumn{2}{|c|}{ Arial } & $=4$ & 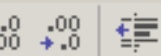 & $=$ & A. & ? &. \\
\hline \multicolumn{8}{|c|}{ E22 } \\
\hline & $\mathrm{A}$ & $\mathrm{B}$ & $\mathrm{C}$ & $\mathrm{D}$ & $E$ & $\mathrm{~F}$ & $\overline{1}$ \\
\hline \multicolumn{7}{|l|}{1} & \\
\hline 2 & $\mathrm{~L}=$ & 0.1 & $\mathrm{~m}$ & & & & \\
\hline 3 & $\delta=$ & 0.01 & $\mathrm{~m}$ & & & & \\
\hline 4 & $w=$ & 0.2 & $\mathrm{~m}$ & & & & \\
\hline 5 & $\mathrm{k}=$ & 54 & $\mathrm{~W} / \mathrm{m}^{\circ} \mathrm{C}$ & & & & \\
\hline 6 & $\mathrm{~T}_{0}=$ & 200 & ${ }^{\circ} \mathrm{C}$ & & & & \\
\hline 7 & $\mathrm{~T}_{\infty}=$ & 10 & ${ }^{\circ} \mathrm{C}$ & & & & \\
\hline 8 & $h=$ & 200 & $\mathrm{~W} / \mathrm{m}^{2.0} \mathrm{C}$ & & & & \\
\hline 9 & $\mathrm{Bi}=\mathrm{h} \delta \mathrm{k}$ & 0.03704 & & & & & \\
\hline 10 & $\mathrm{~m}=2 \sqrt{\mathrm{h} / \mathrm{k} \delta}$ & 38.49 & & & & & \\
\hline 11 & $\mathrm{~mL}=$ & 3.8490 & & & & & \\
\hline 12 & $I_{0}(\mathrm{~mL})=$ & 9.9248 & & & & & \\
\hline 13 & $\mathrm{l}_{1}(\mathrm{~mL})=$ & 8.51004 & & & & & \\
\hline \multicolumn{8}{|l|}{14} \\
\hline 15 & $x, m$ & $\operatorname{m} \sqrt{x I}$ & $\operatorname{Idm} \sqrt{x L}$ & $\theta$ & $\mathrm{T},{ }^{\circ} \mathrm{C}$ & & \\
\hline 16 & 0 & 0 & 1 & 0.101 & 29.144 & & \\
\hline 17 & 0.05 & 2.7217 & 3.9076 & 0.394 & 84.807 & & \\
\hline \multicolumn{8}{|l|}{18} \\
\hline 19 & $q=$ & -677.23 & $\mathrm{~W}$ & & & & -1 \\
\hline 20 & $\eta=$ & 0.4433 & & & & & - \\
\hline \multicolumn{8}{|c|}{ 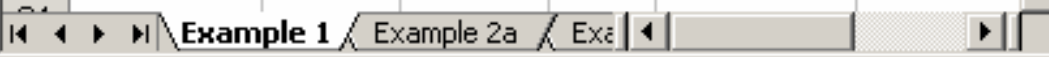 } \\
\hline Read & & & & & & & /la \\
\hline
\end{tabular}

Fig. 4. Solution to Example problem 1 


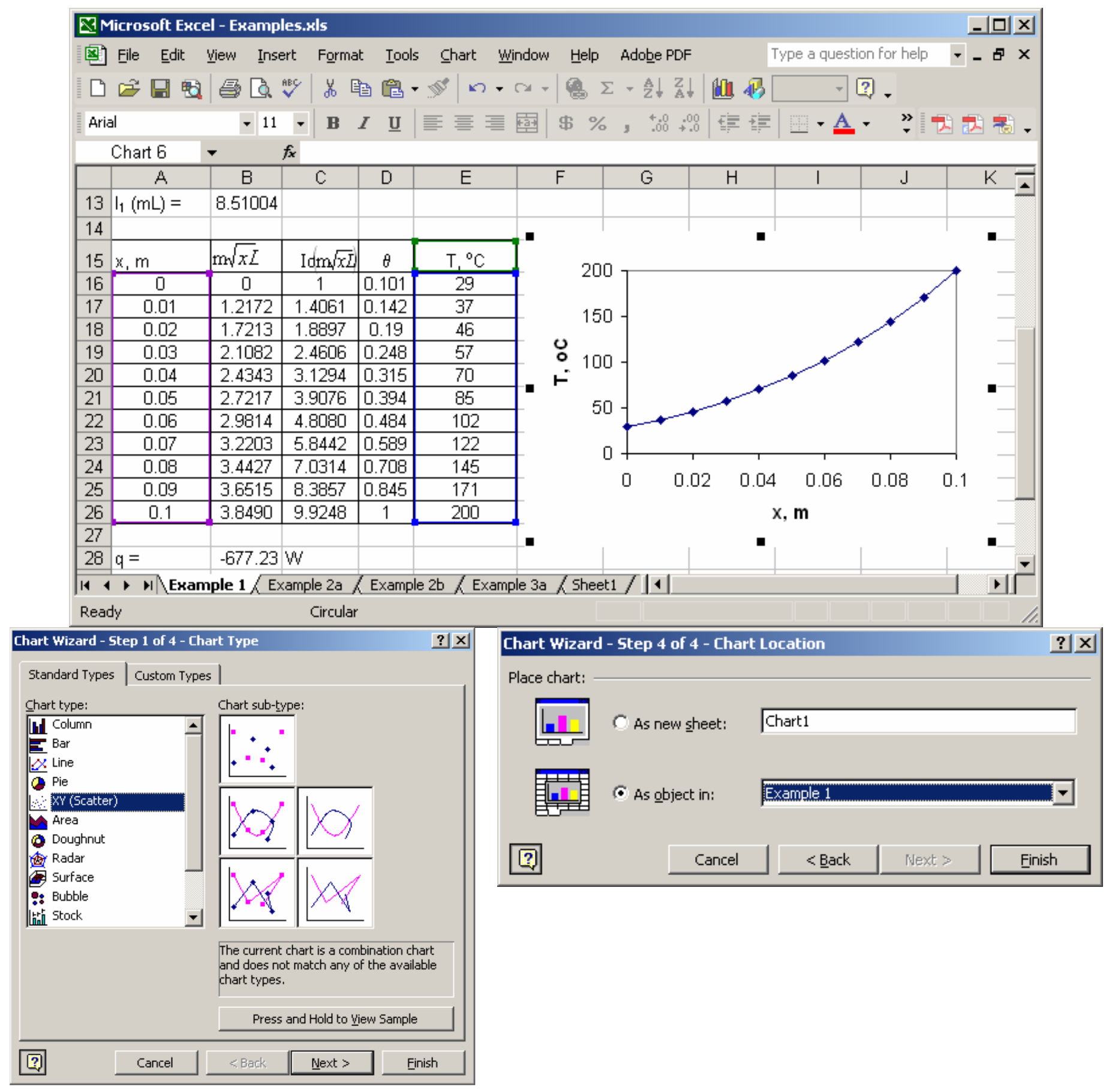

Fig. 5. Procedure for the evaluation and plotting of the temperature profile in Example 1

\section{Example 2:}

A fin of triangular profile (axial section) $0.1 \mathrm{~m}$ in length, $0.02 \mathrm{~m}$ thick at the base, $0.2 \mathrm{~m}$ in depth is used to extend the surface of a wall at $200^{\circ} \mathrm{C}$. The wall and the fin are made of mild steel $(\mathrm{k}=$ $\left.54 \mathrm{~W} / \mathrm{m} \cdot{ }^{\circ} \mathrm{C}\right)$. Air at $10^{\circ} \mathrm{C}\left(\mathrm{h}=200 \mathrm{~W} / \mathrm{m}^{2} \cdot{ }^{\circ} \mathrm{C}\right)$ flows over the surface of the fin. Evaluate the distance from the base where the temperature is $175^{\circ} \mathrm{C}$. 


\section{Solution:}

The solution to this problem is based on the same equations used in the previous example, except in this case the distance, $\mathrm{x}$, cannot explicitly be determined, since it is a part of the Bessel function argument in Eq. 11. A trial and error procedure is required for the solution of this problem.

An Excel spreadsheet can be employed to solve this problem. One method is to use the same solution used in example 1 , but for this problem the desired temperature could be achieved by changing the values of $x$ in the spreadsheet. The result of this procedure is shown in Fig. 6.

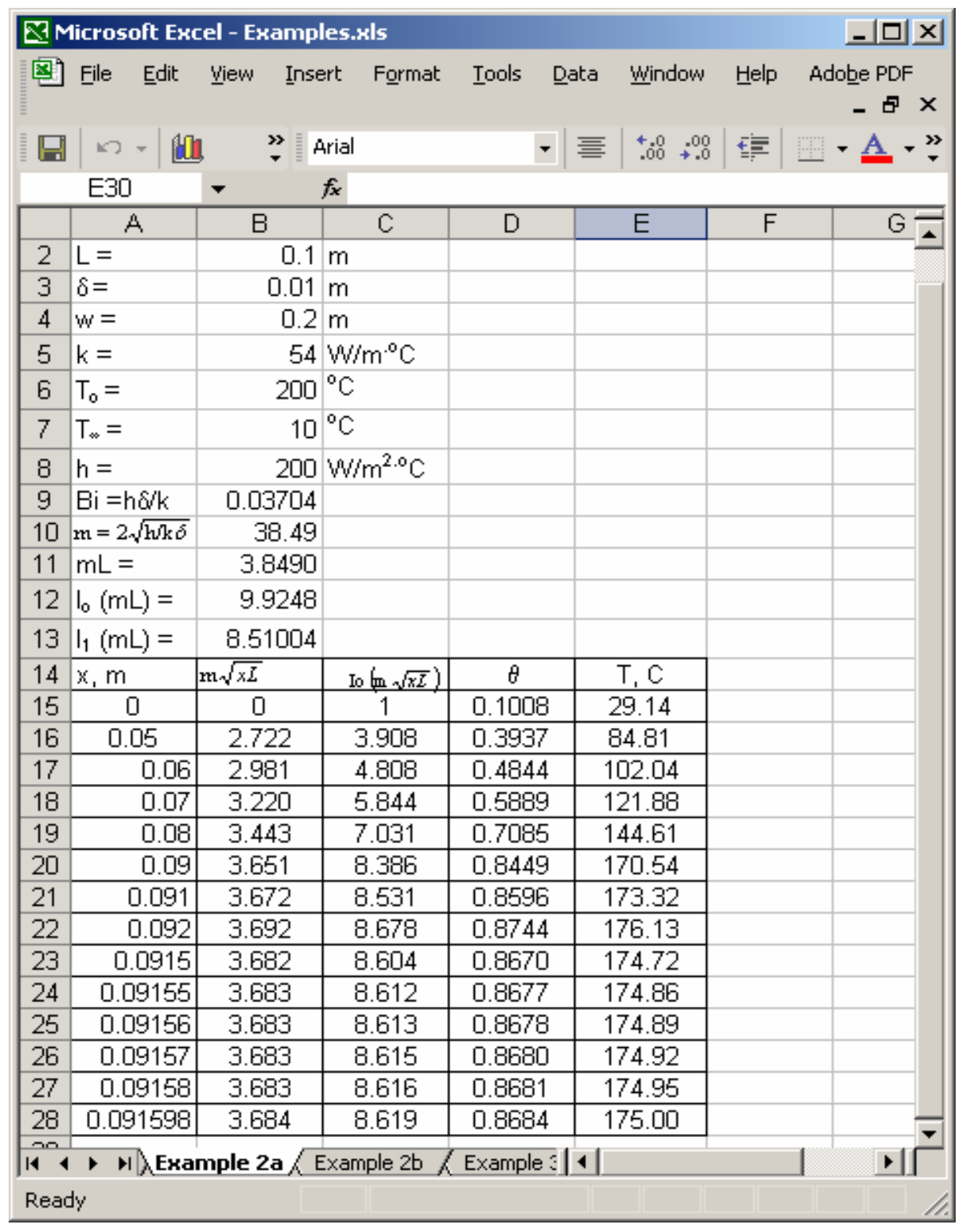

Fig. 6. Solution of Example 2 by a trial and error procedure 
A simpler way to solve the problem in Example 2, is to take the advantage of "Goal Seek" tool in Excel. Figure 7 shows the value of the temperature at an arbitrary position in the fin. By using the tool menu, and selecting the Goal Seek option a dialog box appears, as shown in Fig 7. The target cell (temperature in this case, cell E16) then is selected and its value is set to a desired value for that cell (175). The cell that its value must be changed is identified (cell A16). After clicking the Solve button, the value in the selected cell A16 (x) is automatically changes to a value that gives the desired solution in the target cell (E16) Now the value of $\mathrm{x}$ in Fig. 6 changes so that the temperature is equal to $175^{\circ} \mathrm{C}$. The procedure and the final solution are shown in Fig.7.

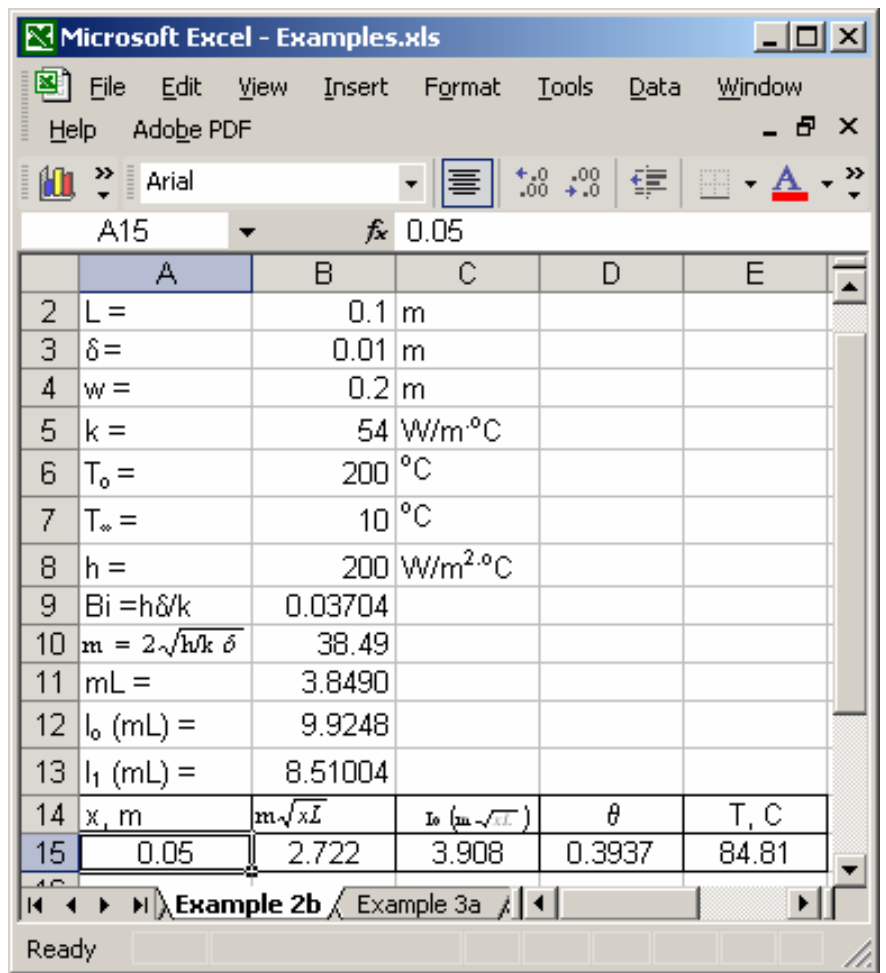

a) Initial guess
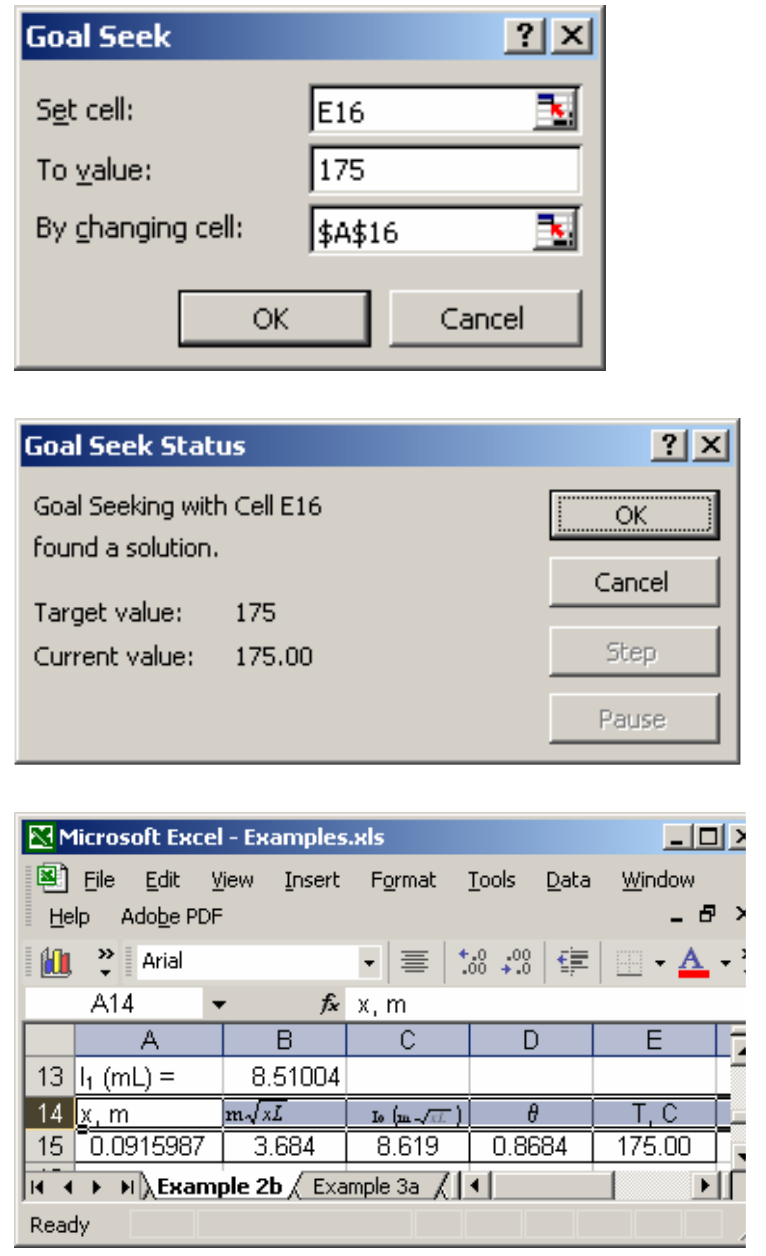

b) Final solution

Fig 7. Procedure of using the Goal Seek tool to find $\mathrm{x}$ where $\mathrm{T}=175^{\circ} \mathrm{C}$. 


\section{Example 3:}

An annular fin of the rectangular profile having a thickness of $2.0 \mathrm{~mm}$ is attached to tube maintained at $120{ }^{\circ} \mathrm{C}$. The inner radius of fin, $\mathrm{r}_{1}$, is $2.0 \mathrm{~cm}$. The environmental temperature is $20^{\circ} \mathrm{C}$, and $\mathrm{h}=70$ $\mathrm{W} /\left(\mathrm{m}^{2} .{ }^{\circ} \mathrm{C}\right)$. The fin is made of $40 \%$ nickel steel $\operatorname{rod}\left[\mathrm{k}=10.0 \mathrm{~W} / \mathrm{m} .{ }^{\circ} \mathrm{C}\right]$. Evaluate the outer radius, $r_{2}$, if the temperature at the tip of the fin is required to be maintained at $95{ }^{\circ} \mathrm{C}$. Also determine the rate of heat transfer and the fin efficiency.

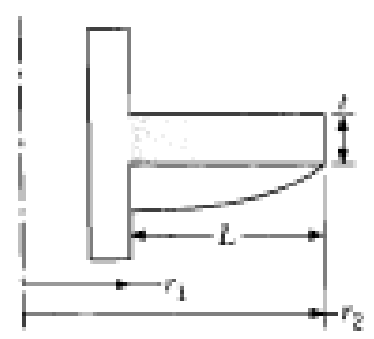

\section{Solution:}

The temperature distribution, assuming insulated tip is given by

$$
\theta=\frac{T-T_{\infty}}{T_{o}-T_{\infty}}=\frac{K_{1}\left(m r_{2}\right) I_{o}(m r)+I_{1}\left(m r_{2}\right) K_{o}(m r)}{K_{1}\left(m r_{2}\right) I_{o}\left(m r_{1}\right)+I_{1}\left(m r_{2}\right) K_{o}(m r)}
$$

where, $\mathrm{r}_{1}$ and $\mathrm{r}_{2}$ are the inner and outer radius of the fin, respectively, $m=\sqrt{2 h / k t}, \mathrm{I}_{\mathrm{o}}$ and $\mathrm{K}_{\mathrm{o}}$ are modified, zero-order Bessel function of the first and second kind, respectively, $\mathrm{I}_{1}$ and $\mathrm{K}_{1}$ are modified, first-order Bessel function of the first and second kind, respectively.

Using $q=-\left.k A \frac{d T}{d r}\right|_{r=r_{1}}$ results in the following expression for the rate heat transfer at the base

$$
q=-2 \pi r_{1} t k\left(T_{o}-T_{\infty}\right) m \frac{K_{1}\left(m r_{2}\right) I_{o}\left(m r_{1}\right)-I_{1}\left(m r_{2}\right) K_{o}\left(m r_{1}\right)}{K_{1}\left(m r_{2}\right) I_{o}\left(m r_{1}\right)+I_{1}\left(m r_{2}\right) K_{o}(m r)}
$$

The fin efficiency can be calculated by substituting Eq. 15 into Eq. 10

$$
\eta_{f}=\frac{q_{a c t}}{q_{\max }}=\frac{q_{a c t}}{h A\left(T_{o}-T_{\infty}\right)}
$$

where, $\mathrm{A}$ in this problem represent the surface area for the convective heat transfer.

$$
A=2 \pi\left(r_{2}^{2}-r_{1}^{2}\right)
$$

Again to solve this problem, one must employ an iterative trial and error procedure, since value of $r_{2}$ used in Eqs. 15 through 16 is unknown. Goal Seek tool was used to conduct the iteration process. The information given in the problem statement and the formulas for the evaluation of $\mathrm{m}, \mathrm{mr}_{1}, \mathrm{mr}_{2}, \mathrm{I}_{\mathrm{o}}\left(\mathrm{mr}_{1}\right), \mathrm{I}_{\mathrm{o}}\left(\mathrm{mr}_{2}\right), \mathrm{I}_{1}\left(\mathrm{mr}_{1}\right), \mathrm{I}_{1}\left(\mathrm{mr}_{2}\right), \mathrm{K}_{\mathrm{o}}\left(\mathrm{mr}_{1}\right), \mathrm{K}_{\mathrm{o}}\left(\mathrm{mr}_{2}\right), \mathrm{K}_{1}\left(\mathrm{mr}_{1}\right), \mathrm{K}_{1}\left(\mathrm{mr}_{2}\right), \theta, \mathrm{T}\left(\mathrm{r}_{2}\right)$, $\mathrm{q}$, and $\eta_{\mathrm{f}}$ were entered into an Excel worksheet. A value of $\mathrm{r}_{2}=0.04$ was used to evaluate the temperature at the tip of the fin. A temperature of $89.3{ }^{\circ} \mathrm{C}$ was calculated by the formulas in Excel, as shown in Fig. 8. The Goal Seek tool was used by setting a target value of $95{ }^{\circ} \mathrm{C}$ for the tip of the fin (Cell H17). The goal Seek calculated a value of $r_{2}=0.0422 \mathrm{~m}$, as shown in Fig. 9 and $q$, and $\eta_{\mathrm{f}}$ were recalculated by Excel, based on the new value for $r_{2}$. 


\begin{tabular}{|c|c|c|c|c|c|c|c|c|c|}
\hline \multicolumn{8}{|c|}{ 区 Microsoft Excel - Examples.sls } & \multicolumn{2}{|c|}{$-|\square| x$} \\
\hline \multicolumn{3}{|c|}{ 图 Eile Edit Wiew Insert } & sert Format & Iools & Data $\underline{\text { Win }}$ & dow $\underline{\text { Help }}$ & Adobe PDF & - 皇 & $\times$ \\
\hline \multicolumn{4}{|c|}{ 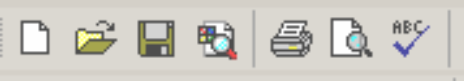 } & $\Leftrightarrow \mid n$ & 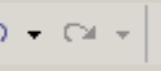 & $\Sigma \cdot \frac{\mathrm{A}}{\mathrm{Z}} \downarrow$ & $100 \%$ & - ? & 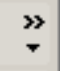 \\
\hline \multicolumn{2}{|c|}{ Arial } & -10. & $\mathbf{B} I$ & \multicolumn{2}{|c|}{ 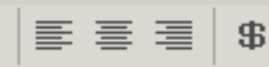 } & \multicolumn{4}{|c|}{ 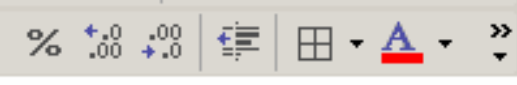 } \\
\hline \multicolumn{2}{|r|}{ F21 } & \multicolumn{8}{|c|}{ 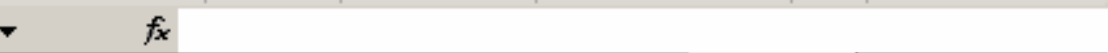 } \\
\hline & $\mathrm{A}$ & $\mathrm{B}$ & $\mathrm{C}$ & $\mathrm{D}$ & $E$ & F Form & nula Bar & $\mathrm{H}$ & $\bar{\nabla}$ \\
\hline \multicolumn{10}{|l|}{1} \\
\hline 2 & $r_{1}=$ & 0.02 & $m$ & & & & & & \\
\hline 3 & $t=$ & 0.002 & m & & & & & & \\
\hline 4 & $k=$ & 10 & $\mathrm{~W} / \mathrm{m}^{\circ} \mathrm{C}$ & & & & & & \\
\hline 5 & $\mathrm{~T}_{0}=$ & 120 & & & & & & & \\
\hline 6 & $\mathrm{~T}_{\infty}=$ & 20 & ${ }^{\circ} \mathrm{C}$ & & & & & & \\
\hline 7 & $h=$ & 70 & & & & & & & \\
\hline 8 & $\mathrm{Bi}=\mathrm{ht} / \mathrm{k}$ & 0.01400 & $\mathrm{~W} / \mathrm{m}^{2.0} \mathrm{C}$ & & & & & & \\
\hline 9 & $m=\sqrt{2 h / h t}$ & 83.67 & & & & & & & \\
\hline 10 & $\mathrm{mr}_{1}=$ & 1.6733 & & & & & & & \\
\hline 11 & $I_{0}\left(m r_{1}\right)=$ & 1.8325 & & & & & & & \\
\hline 12 & $l_{1}\left(m r_{1}\right)=$ & 1.16572 & & & & & & & \\
\hline 13 & $K_{0}\left(m r_{1}\right)=$ & 0.1712 & & & & & & & \\
\hline 14 & $K_{1}\left(m r_{1}\right)=$ & 0.2172 & & & & & & & \\
\hline 15 & & & & & & & & & \\
\hline 16 & $r_{2}, m$ & $\mathrm{mr}_{2}$ & $\mathrm{I}_{0}\left(\mathrm{mr}_{2}\right)$ & $l_{1}\left(\mathrm{mr}_{2}\right)$ & $K_{0}\left(m_{2}\right)$ & $\mathrm{K}_{1}\left(\mathrm{mr}_{2}\right)$ & $\theta$ & $\mathrm{T}\left(\mathrm{r}_{2}\right),{ }^{\circ} \mathrm{C}$ & \\
\hline 17 & 0.04 & 3.3466 & 6.48943 & 5.40357 & $\begin{array}{l}0.02333 \\
\end{array}$ & 0.02662 & 0.306850 & 89.315 & \\
\hline 18 & $q=$ & 24.677 & W & & & & & & \multirow{2}{*}{-} \\
\hline 19 & $\eta_{\mathrm{f}}=$ & 0.4675 & & & & & & & \\
\hline \multicolumn{10}{|c|}{ 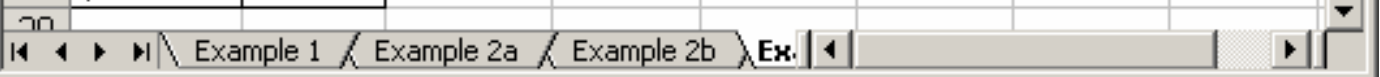 } \\
\hline Read & & & & & & & & & $1 /$ \\
\hline
\end{tabular}

Fig 8. Initial guess for $\mathrm{r}_{2}$, in solving the problem in Example 3.

\section{Example 4:}

A carbon steel bar $\left(\mathrm{k}=54.0 \mathrm{~W} / \mathrm{m} .{ }^{\circ} \mathrm{C}\right) 40 \mathrm{~cm}$ long connects two thermal reservoirs, one at $200{ }^{\circ} \mathrm{C}$ and the other at $100^{\circ} \mathrm{C}$. The bar has a diameter of $1.5 \mathrm{~cm}$. Air at $25^{\circ} \mathrm{C}$ flows across the bar. Evaluate the desired air free stream velocity, if the temperature of the fin at a location $30 \mathrm{~cm}$ from the $200{ }^{\circ} \mathrm{C}$ wall must be equal $68{ }^{\circ} \mathrm{C}$. The following information is provided for air at 450 $\mathrm{K}: \rho_{\mathrm{a}}=0.7846 \mathrm{~kg} / \mathrm{s}, \mathrm{c}_{\mathrm{p}, \mathrm{a}}=1020 \mathrm{~J} / \mathrm{kg} . \mathrm{K}, \mu_{\mathrm{a}}=2.493 \mathrm{E}^{-05} \mathrm{~N} . \mathrm{s} / \mathrm{m}, v_{\mathrm{a}}=3.177 \mathrm{E}^{-05} \mathrm{~m}^{2} / \mathrm{s}, \mathrm{k}_{\mathrm{a}}=0.03633$ $\mathrm{W} / \mathrm{m} . \mathrm{K}, \alpha_{\mathrm{a}} \mathrm{m}^{2} / \mathrm{s}=0.698$, and $\operatorname{Pr}_{\mathrm{a}}=0.698$. 


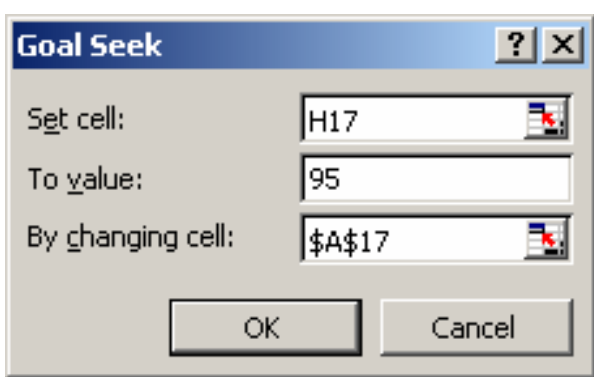

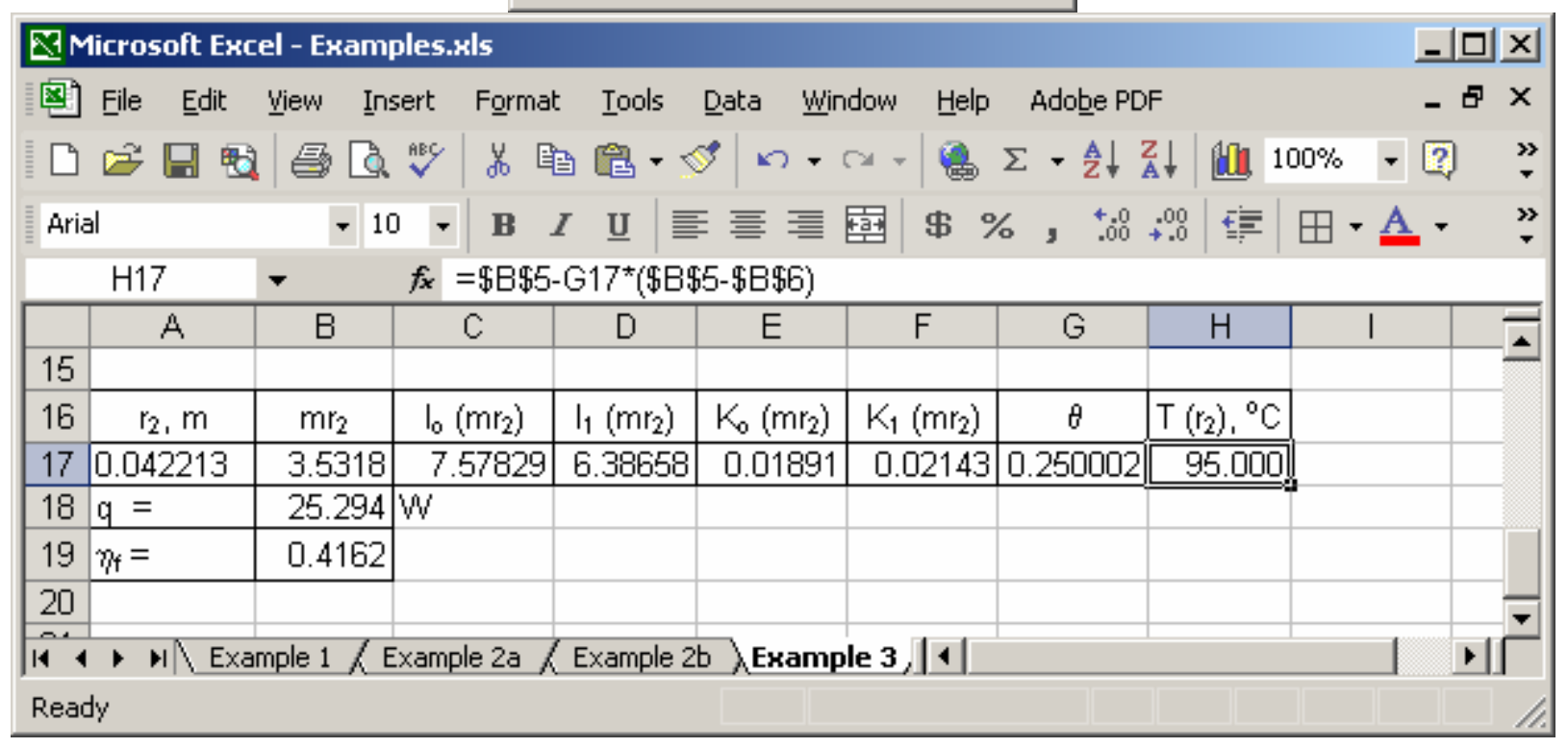

Fig. 9. Solution to Example 3 problem, using Goal Seek

\section{Solution:}

In this problem, the temperature at $\mathrm{x}=0.3 \mathrm{~m}$ could be calculated from Eq. 7 if the value for heat transfer coefficient was

$$
\theta=\frac{T-T_{\infty}}{T_{o}-T_{\infty}}=\frac{\left[\left(T_{L}-T_{\infty}\right) /\left(T_{o}-T_{\infty}\right)\right] \sinh (m x)+\sinh [m(L-x)]}{\sinh (m L)}
$$

where, $m=\sqrt{2 h / k_{m} R}, \mathrm{k}_{\mathrm{m}}$ is the thermal conductivity of the bar.

For air flow over a cylinder the Reynolds number is defined as

$$
\operatorname{Re}_{D}=\frac{h D}{k_{a}}
$$

where, $\mathrm{k}_{\mathrm{a}}$ is the thermal conductivity of air. The Nusselt number can be obtained from the relationship given by Churchill and Bernstine ${ }^{22}$

$$
\begin{array}{r}
N u_{D}=\frac{h D}{k}=0.3+\frac{0.62 \operatorname{Re}_{D}^{0.5} \operatorname{Pr}^{1 / 3}}{\left[1+(0.4 / / \operatorname{Pr})^{2 / 3}\right]^{1 / 4}}\left[1+\left(\frac{\operatorname{Re}_{D}}{282,000}\right)^{5 / 8}\right]^{0.8} \\
\quad \text { for } 100<\operatorname{Re}_{\mathrm{D}}<10^{7} ; \operatorname{Pe}_{\mathrm{D}}=\operatorname{Re}_{\mathrm{D}} * \operatorname{Pr}>0.2
\end{array}
$$


The data given in the problem statement for the bar and air were entered into cells of a worksheet as shown in Fig. 10. A free stream velocity of $1.0 \mathrm{~m} / \mathrm{s}$ was assumed for air (Cell A13). The appropriate formulas for the evaluation of $\mathrm{Re}_{\mathrm{D}}, \mathrm{Nu}_{\mathrm{D}} \mathrm{h}, \mathrm{Bi}, \mathrm{m}, \mathrm{mL}, \mathrm{mx}, \theta$, and $\mathrm{T}(\mathrm{x}=0.3 \mathrm{~m})$ were entered into the spreadsheet cells. Based on the assumed value of the free stream velocity a temperature of 79.8 was calculated for $\mathrm{T}$. Then the Solver tool was used to set the target value in cell F16 to $68^{\circ} \mathrm{C}$. As shown in Fig 11, the Solver calculated an air velocity of $4.69 \mathrm{~m} / \mathrm{s}$ necessary for the temperature to be $68{ }^{\circ} \mathrm{C}$ at $\mathrm{x}=0.3 \mathrm{~m}$.

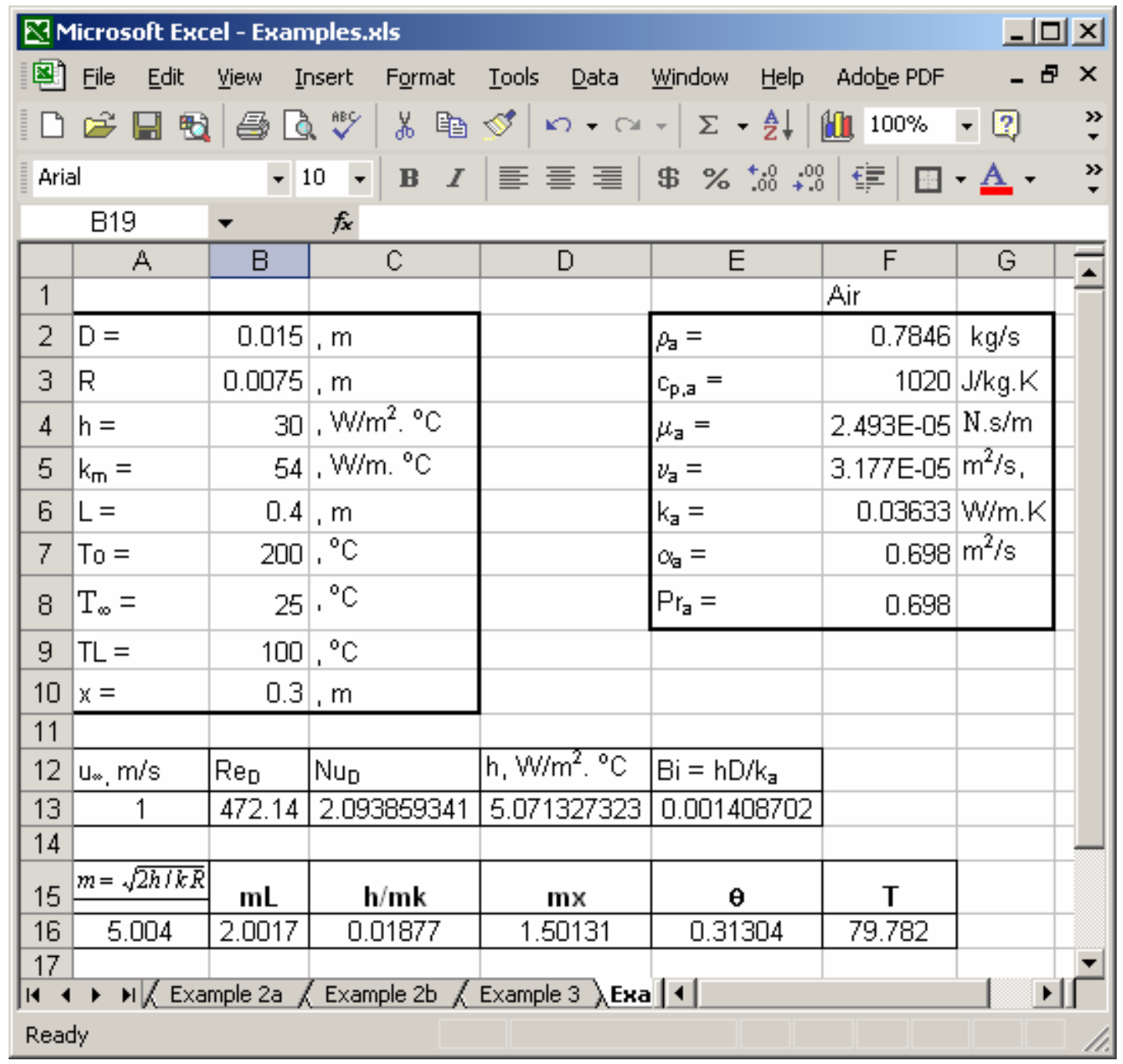

Fig. 10. The temperature at $x=0.3 \mathrm{~m}$, based on an initial guess of $1.0 \mathrm{~m} / \mathrm{s}$ for the air velocity

\section{Discussion}

The examples used above, demonstrated that excel is an effective tool in solving fin heat conduction problems. Its application simplifies the evaluation of temperature distribution and 
the rate of heat transfer when solving problems involving extended surfaces. The heat transfer solutions obtained from the application of Excel is more accurate than those calculated from fin efficiency charts.

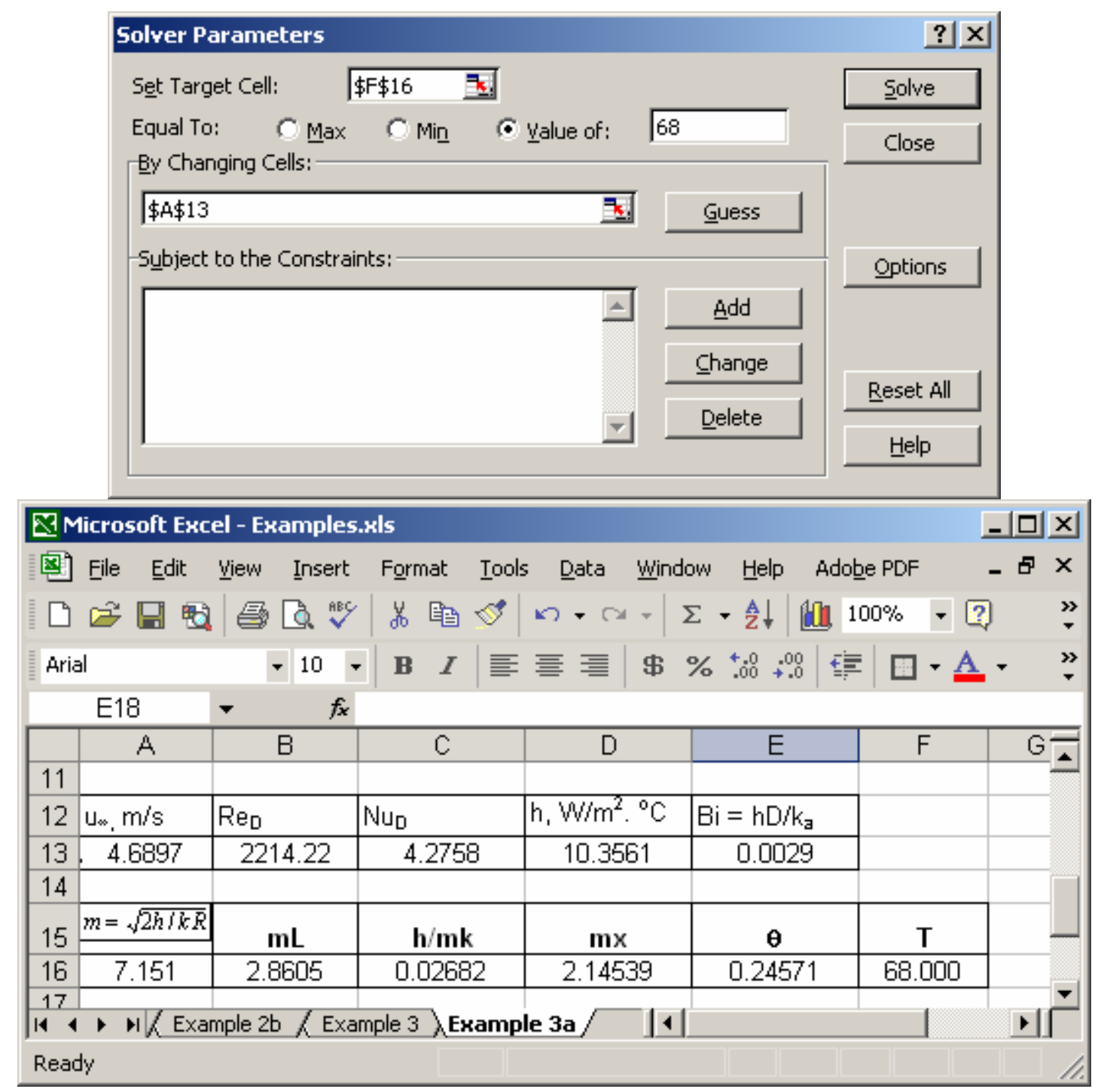

Fig. 11. Solution to Example problem 3, using the Excel's Solver tool.

Excel can easily be integrated into a heat transfer course. Most students are already familiar with the basic operation of Excel. This includes entering data into the spreadsheet and plotting simple graphs. However, it is possible that few students might not know how to enter formulas into the worksheet cells. Perhaps, most have never used the Goal Seek, and Solver tools in solving engineering problems.

An introduction to application of Excel in solving heat transfer problem takes 30 to 45 minutes of class time to demonstrate how to enter formulas into cells of Excel worksheet. The 
application of Goal Seek and Solver tools could be demonstrated through simple examples.

We have not yet integrated Excel into our undergraduate heat transfer course. However in teaching a heat conduction course to a small class of first year graduate course, students were asked to plot the fin efficiency curves for several types of fins. None of the students had used the Goal Seek or Solver tools of Excel. A short lecture was given on the use of these tools. Students were given the option of using Excel, IHT, EES, or similar software for plotting the curves. All students selected to use Excel to complete their assigned project. The main reason was the convenience and the availability of Excel of student personal computers.

\section{Summary}

The application of Excel spreadsheet in solving one dimensional heat conduction problems was demonstrated through several examples. It was shown that Excel is a useful computational tool when the solution to problems requires (a) varying one of the parameters, (b) plotting the results of calculations, and (c) an iteration process.

\section{References}

1. Kreith, F., 1965, Principles of Heat Transfer, Second Edition, International Book Company, New York.

2. Bayley, F. J, Owen, M.J, and Turner, A. B, 1972, Heat Transfer, Barnes and Noble, New York.

3. Chapman, A. J, 1974, Fundamentals of Heat Transfer, Macmillan, New York.

4. Wolf, H., 1983, Heat Transfer, Harper and Row Publishers, New York

5. White, F., 1984, Heat Transfer, 1984, Addison-Wesley Publishing, Reading, Massachusetts.

6. Ozisik, M. N., 1985, Heat Transfer, A Basic Approach, McGraw Hill, New York.

7. Lienhard, John, 1981, A Heat Transfer Textbook, Prentice-Hall.

8. Thomas, A.C., 1992, Heat Transfer, Prentice Hall, New Jersey.

9. Holman, J.P., 2002, Heat Transfer, Ninth Edition, New York.

10. Mills, A.F., 1999, Basic Heat and Mass Transfer, $2^{\text {nd }}$ edition, Prentice Hall, New Jersey.

11. Incropera, F. P., De Witt, D.P., Bergman, T. L., Lavin, A.S., 2007, Introduction to Heat Transfer, Fifth Edition, John Wiley, New York.

12. Cengel, Y. A., 2003, Heat Transfer, A Practical Approach, Second Edition, McGraw Hill, New York.

13. Cengel Y. A., Turner, R. H., 2005, Fundamentals of Thermal-Fluid Sciences, $2^{\text {nd }}$ Edition, McGraw Hill, New York.

14. Moran, M. J., Shapiro, H. N., Munson, B. R., and DeWitt, D. P., 2003, Introduction to Thermal Systems Engineering: Thermodynamics, Fluid Mechanics, and Heat Transfer, John Wiley, New York.

15. Kaviany, M., 2002, Principles of Heat Transfer, John Wiley, New York.

16. Smith, T. F. and Wen, J. 2002, Interactive Heat Transfer, V.2.0, John Wiley, New York.

17. Beckman, W. A., and Klein, S. A., 2004, http://www.fchart.com/ees/ees.shtml

18. Fakhri, A., 2004, "Spreadsheet Solution of the Boundary Layer Equations," IMECE2004-59515, Proceedings of 2004 International Mechanical Engineering Congress and Exposition, Anaheim. California.

19. Naraghi, M H. 2004, "Solution of Similarity Transform Equation for Boundary Layers Using Spreadsheets," IMECE2004-61491, Proceedings of 2004 International Mechanical Engineering Congress and Exposition, Anaheim. California.

20. Karimi, A, Deleon, J., and Hannan, M. 2007, "A Review of Available Computer Software Packages for Use in an Undergraduate Heat Transfer Course," IMECE2007-43289, Proceedings of 2007 International Mechanical Engineering Congress and Exposition, Seattle, Washington.

21. Kraus, A., Aziz, A., and Welty, J., 2001, Extended Surface Heat Transfer, Wiley Inter-Science, New York.

22. Churchill, S. W., and Bernstein, 1977, "A Correlation Equation for Forced Convection from Gases and Liquids to a Circular Cylinder in Crossflow" J. Heat Transfer, vol. 99, pp. 300-306. 


\section{Nomenclature}

$\mathrm{A}=\quad$ surface area or cross-sectional area, $\mathrm{m}^{2}$

$\mathrm{h}=$ heat transfer coefficient, $\mathrm{W} / \mathrm{m}^{2} \cdot \mathrm{K}$

$\mathrm{I}_{\mathrm{O}}(\mathrm{x}), \mathrm{I}_{1}(\mathrm{x})=$ modified Bessel function of the first kind of order zero, order one

$\mathrm{K}_{\mathrm{o}}(\mathrm{x}), \mathrm{K}_{1}(\mathrm{x})=$ modified Bessel function of the first kind of order zero, order one

$\mathrm{J}_{\mathrm{o}}(\mathrm{x})$ or $\mathrm{J}_{1}(\mathrm{x})=$ Bessel function of the first kind of order zero or order one

$\mathrm{k}=\quad$ thermal conductivity, $\mathrm{W} / \mathrm{m} \cdot \mathrm{K}$

$\mathrm{L}=$ length, $\mathrm{m}$

$\mathrm{Nu}=$ Nusselt number

$\mathrm{Re}=$ Reynold number

$\mathrm{q}=$ heat transfer rate, $\mathrm{W}$

$\mathrm{T}=$ temperature, ${ }^{\circ} \mathrm{C}$ or $\mathrm{K}$

Greek letters

$\alpha=$ thermal diffusivity, $\mathrm{m}^{2} / \mathrm{s}$

$\theta=$ dimensionless temperature parameter, a ratio of temperature differences

$\eta_{f}=$ fin efficiency

Subscripts

$\mathrm{f}=\quad$ fin

$\mathrm{o}=\quad$ location at $\mathrm{x}=0$

$\infty=$ ambient condition

\section{Greek letters}

\begin{tabular}{ll}
\hline$\Delta$ & difference \\
$\varepsilon$ & heat exchanger effectiveness \\
$\mu$ & $\quad$ viscosity, N.s $/ \mathrm{m}$ \\
$\nu$ & kinematic viscosity, $\mathrm{m}^{2} / \mathrm{s}$
\end{tabular}




\section{Appendix}

Table A. Temperature distribution equation for common fins

\begin{tabular}{|c|c|c|}
\hline $\begin{array}{l}\text { Straight fin, } \\
\text { rectangular } \\
\text { profile }\end{array}$ & & $\begin{array}{l}\theta=\frac{T-T_{\infty}}{T_{o}-T_{\infty}}=\frac{\cosh [m(L-x)]}{\cosh (m L)} \\
m=\sqrt{2 h / k t} \\
\mathrm{x} \text { is measured from the base }\end{array}$ \\
\hline $\begin{array}{l}\text { Straight fin, } \\
\text { triangular } \\
\text { profile }\end{array}$ & & $\begin{array}{l}\theta=\frac{T-T_{\infty}}{T_{o}-T_{\infty}}=\frac{I_{o}(2 \sqrt{h L(L-x) / k t})}{I_{o}\left(2 \sqrt{h L^{2} / k t}\right)}=\frac{I_{o}(m L \sqrt{(1-x / L)})}{I_{o}(m L)} \\
m=\sqrt{2 h / k t} \\
\mathrm{x} \text { is measured from the base }\end{array}$ \\
\hline $\begin{array}{l}\text { Straight fin, } \\
\text { concave } \\
\text { parabolic } \\
\text { profile }\end{array}$ & & $\begin{array}{l}\theta=\frac{T-T_{\infty}}{T_{o}-T_{\infty}}=\left(1-\frac{x}{L}\right)^{\left[\sqrt{\frac{1}{4}+(m L)^{2}}-\frac{1}{2}\right]} \\
m=\sqrt{2 h / k t} \\
\mathrm{x} \text { is measured from the base }\end{array}$ \\
\hline $\begin{array}{l}\text { Annular fin, } \\
\text { rectangular } \\
\text { profile }\end{array}$ & & $\begin{array}{l}\theta=\frac{T-T_{\infty}}{T_{o}-T_{\infty}}=\frac{K_{1}\left(m r_{2}\right) I_{o}(m r)+I_{1}\left(m r_{2}\right) K_{o}(m r)}{K_{1}\left(m r_{2}\right) I_{o}\left(m r_{1}\right)+I_{1}\left(m r_{2}\right) K_{o}(m r)} \\
m=\sqrt{2 h / k t}\end{array}$ \\
\hline $\begin{array}{l}\text { Pin fin, } \\
\text { rectangular } \\
\text { profile }\end{array}$ & & $\begin{array}{l}\theta=\frac{T-T_{\infty}}{T_{o}-T_{\infty}}=\frac{\cosh [m(L-x)]}{\cosh (m L)} \\
m=2 \sqrt{h / k D}\end{array}$ \\
\hline $\begin{array}{l}\text { Pin fin, } \\
\text { trianglular } \\
\text { profile }\end{array}$ & & $\begin{array}{l}\theta=\frac{T-T_{\infty}}{T_{o}-T_{\infty}}=\left(\sqrt{\frac{L}{L-x}}\right) \frac{I_{1}(2 m \sqrt{L-x})}{I_{1}(2 m \sqrt{L})} \\
m=2 \sqrt{h L / k D} \\
\mathrm{x} \text { is measured from the base }\end{array}$ \\
\hline $\begin{array}{l}\text { Pin fin, } \\
\text { concave } \\
\text { parabolic } \\
\text { profile }\end{array}$ & & $\begin{array}{l}\theta=\frac{T-T_{\infty}}{T_{o}-T_{\infty}}=\left(1-\frac{x}{L}\right)^{\left[\sqrt{9+4(m L)^{2}}-\frac{3}{2}\right]} \\
m=2 \sqrt{h / k D} \\
\mathrm{x} \text { is measured from the base }\end{array}$ \\
\hline
\end{tabular}


Table B. Fin Efficiency Equations ${ }^{10}$

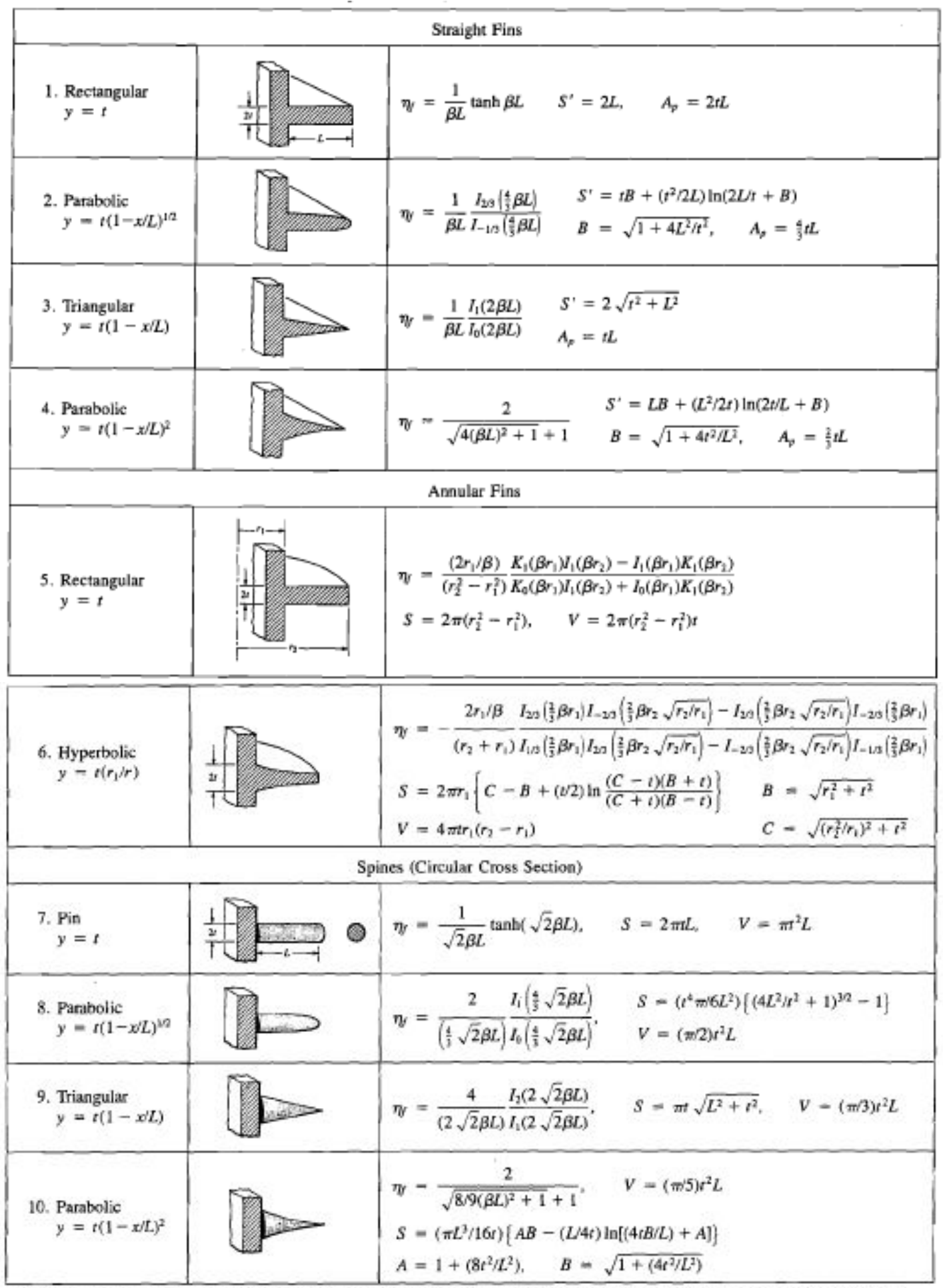

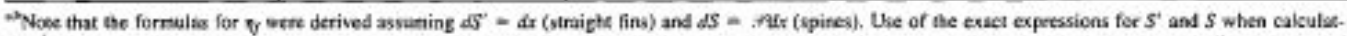

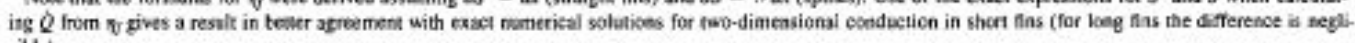
siblex. 